\title{
Effect of Depth of Tuber Planting on Growth and Yield Parameters of Potato Crop
}

\author{
Navneet Singh $^{1}$, Amandeep Singh ${ }^{2}$ and Kanwaljit Singh ${ }^{1}$ \\ ${ }^{1}$ PG Department of Agriculture, Khalsa College Amritsar, India \\ ${ }^{2}$ Department of Plant Pathology, Punjab Agricultural University, Ludhiana, India \\ *Corresponding author
}

\begin{tabular}{l} 
K e y w o r d s \\
Growth and yield, \\
Potato crop, \\
Plant height \\
\hline Article Info \\
\hline $\begin{array}{l}\text { Accepted: } \\
18 \text { April } 2020 \\
\text { Available Online: } \\
\text { 10 May } 2020\end{array}$ \\
\hline
\end{tabular}

\section{A B S T R A C T}

To view the effect of depth of planting on growth and yield parameters of potato (Solanum tuberosum L.) crop, the experiments were conducted at Students Research Farm, Khalsa College Amritsar. The experiments were conducted at three different depths of planting as treatments viz., D1 (3"), D2 (5”) and D3 (7”) and each treatment was replicated three times. The data had been recorded at their respective stages of growth and total yield were measured at the end of the season of the potato crop. It was found that maximum number of stems per plant was 6.07 recorded in $\mathrm{D}_{2}$ treatment along with maximum plant height of $43.20 \mathrm{~cm}$ and maximum leaf area index of 3.14 as compared to other treatments. The maximum tuber yield was $203 \mathrm{q} / \mathrm{ha}$ and highest number of tubers per plant (7.60) was found in D2 treatment. The study also revealed that the number of tubers per plant decreased as the depth of planting increased. The shallow and deeper depth of planting would reduce the tuber yield due to delay in plant tuber emergence and unfavorable development soil condition and shallow planting also result in reduced the length of stolons which reduced the yield significantly.

\section{Introduction}

Potato (Solanum tuberosum L.) is an annual herbaceous tuber crop, belonging to the family Solanaceae (Sayed et al., 2013). It has good nutritive value as it contains starch, sugar, crude fiber, proteins, amino acids, vitamin $\mathrm{C}$ and essential minerals $(\mathrm{P}, \mathrm{Ca}, \mathrm{Mg}$, $\mathrm{K}, \mathrm{S}$, and $\mathrm{Cl}$ ). This crop has immense potential of solving hunger and malnutrition problem of the country's ever growing population. There are many factors affecting the successful cultivation of potatoes but depth and date of planting of potato tubers are two major factors which effects the growth, quality and yield of crop.

Yield is greatly influenced by depth of seed tubers. To obtain a homogeneous culture, the tubers should be distributed evenly with a specific spacing between rows and a uniform planting depth (Sayed et al., 2013). 
In addition, Lambion et al., (2006) advocated that deeper planting may also limit the damage to tubers by certain pests. In addition to planting depth, crop yield is also influenced by variety, soil, temperature (Gopal et al., 1998), photoperiod (Pruski et al., 2001), light intensity (Gopal et al., 1998), nitrogen nutrition (Etemad and Sarajuoghi, 2012), potassium (Naik and Sarkar, 1998), planting density, plant height, the number of stems on the surface, number of tubers formed by size. Present study was done to evaluate the effect of depth of sowing tubers on growth and yield of crop.

\section{Materials and Methods}

\section{Location and climate}

Amritsar is located at $31^{\circ}-38^{\prime}$ North latitude and $74^{\circ}-52^{\prime}$ East longitude and altitude of 236 meters above sea level. The climate is generally semi humid with extreme winters and summers. The maximum temperature of about $45-48^{\circ} \mathrm{C}$ is not uncommon during summer, while freezing temperature accompanied by frost occurrence may be witnessed in the months of December and January. The total annual rainfall witnessed is about $75 \mathrm{~cm}$.

\section{Treatment and design}

The treatments were done on variety (Lady Rosetta) at three different depths- $\mathrm{D}_{1}$ (3 inch), $\mathrm{D}_{2}(5 \mathrm{inch})$ and $\mathrm{D}_{3}(7$ inch). The area of plot taken was $3 \times 3 \mathrm{~m}^{2}$. Plants in the central rows were used for determination of agronomic performance, leaving aside those in the two border rows as well as those at both ends of each row to avoid edge effects.

\section{Measured parameters}

The following growth parameters viz., days taken to tuber emergence, number of stems per hill at 60 DAP, plant height at 60 DAP, leaf area index and yield characteristic had been recorded.

\section{Results and Discussion}

\section{Growth parameters}

\section{Days taken to tuber emergence}

From table 1, it is revealed that tuber emergence is directly related to depth of planting i.e. maximum number of days taken to emergence was treatment $\mathrm{D}_{3}$ (16.7 days) followed by $\mathrm{D}_{2}$ and $\mathrm{D}_{1}$. Kumar et al., (2015) reported the maximum tuber emergence (98.9 percent) at $10 \mathrm{~cm}$ depth of planting as compared to 15 and $20 \mathrm{~cm}$ depth of planting.

\section{Number of stems per hill}

Table 1 showed that maximum number of stems per hill was 6.07 recorded in $\mathrm{D}_{2}$ treatment followed by $D_{1}$ and $D_{3}$, respectively. Similarly, Kumar et al., (2015) recorded maximum number of stem per plant were 4.38 at $10 \mathrm{~cm}$ depth of plant as compared to 3.88 and 3.38 at 15 and $20 \mathrm{~cm}$ depth of planting.

\section{Plant height}

Plants obtained maximum height of $43.2 \mathrm{~cm}$ $\left(\mathrm{D}_{2}\right)$ followed by $38.1 \mathrm{~cm}\left(\mathrm{D}_{1}\right)$ and $37.0\left(\mathrm{D}_{3}\right)$ respectively. Kumar et al., (2015) observed that plants have similar height $52 \mathrm{~cm}$ at 10 and $15 \mathrm{~cm}$ depth of planting, but the plant height were significantly reduced when the tubers were planted at $20 \mathrm{~cm}$ depth.

Hamid Reza Arab et al., (2011) found taller plants at $20 \mathrm{~cm}$ depth of planting as compare to 30 and $10 \mathrm{~cm}$ depth of planting. It is found that with the increase in planting depth, the height of plant decreased. Similar results were also found by Abbasifar et al., (1995). 
Table.1 Effect of depth of planting on growth parameters of potato crop

\begin{tabular}{|c|c|c|c|c|}
\hline $\begin{array}{c}\text { Planting } \\
\text { depth }\end{array}$ & $\begin{array}{c}\text { Days taken to } \\
\text { tuber emergence }\end{array}$ & $\begin{array}{c}\text { No. of stems } \\
\text { per hill }\end{array}$ & $\begin{array}{c}\text { Plant } \\
\text { Height }(\mathbf{c m})\end{array}$ & $\begin{array}{c}\text { Leaf area } \\
\text { index }\end{array}$ \\
\hline D1 (3") & 14.80 & 5.10 & 38.30 & 2.11 \\
\hline D2 (5”) & 15.70 & 6.00 & 43.20 & 3.14 \\
\hline D3 (7") & 16.70 & 4.50 & 37.00 & 2.60 \\
\hline CD (0.05\%) & 1.12 & 0.37 & 2.28 & 0.15 \\
\hline
\end{tabular}

Table.2 Effect of depth of planting on yield parameters of potato crop

\begin{tabular}{|c|c|c|}
\hline Planting depth & No. of tubers per plant & Total tuber yield (q/ha) \\
\hline D1 (3") & 5.60 & 185.80 \\
\hline D2 (5)) & 7.60 & 203.00 \\
\hline D3 (7") & 5.00 & 173.40 \\
\hline CD (0.05\%) & 0.47 & 11.60 \\
\hline
\end{tabular}

\section{Leaf area index}

Maximum leaf area index (3.14) had been observed in D2 treatment followed by the 2.60 and 2.11 in D3 and D1 treatment, respectively. Ilyas et al., (2017) also observed the maximum leaf area under optimum depth condition, as too much shallow and deep planting significantly affect the leaf area index.

\section{Yield parameters}

Among yield parameters, the number of tubers per plant was significantly higher in $\mathrm{D}_{2}$ treatment (7.6) followed by $\mathrm{D}_{1}(5.6)$ and $\mathrm{D}_{3}$ (5.0), respectively (Table 2). Similarly, maximum number of tubers per plant (9.69) at $10 \mathrm{~cm}$ depth of planting followed by 8.97 and 8.34 at 15 and $20 \mathrm{~cm}$ depth of planting were observed by Kumar et al., (2015) and Bohl et al., (2011). Hamid Reza Arab et al., (2011) observed that $20 \mathrm{~cm}$ depth of planting produced highest number of tubers per plant (5.46) as compared to 10 and $30 \mathrm{~cm}$ depth of planting, respectively. From table 2, it is further revealed that the number of tubers per plant decreased as the depth of planting increased. Gholipour (1996) also reported that the number of tubers per plant is inversely related to depth of tubers.

\section{Total tuber yield}

Maximum total tuber yield was recorded in treatment $\mathrm{D}_{2}(203.0 \mathrm{q} / \mathrm{ha})$ followed by $\mathrm{D}_{1}$ (185.8 q/ha) and least in $\mathrm{D}_{3}(173.4 \mathrm{q} / \mathrm{ha})$. Kumar et al., (2015) found maximum tuber yield of 567.9 thousand per hectare at $10 \mathrm{~cm}$ depth of planting. The shallow and deeper depth of planting would reduce the tuber yield due to delay in plant tuber emergence and unfavorable development soil condition (Bohl and Love, 2005). The shallow planting of tuber in upper layer of soil resulted in closer setting of tubers further attributed to the reduced length of stolons which ultimately leads to reduction in tuber yield (Kumar et al., 2015).

\section{References}

Abbasifar A S, Kashi and Ghafari H (1996) Study of the effects of planting depth on potato yield (Two crops of spring and autumn). Proceedings of the second 
conference on research and treatment liquid vegetables, Karaj, Iran. pp: 4-7.

Bohl W H and Love S L (2005) Effect of planting depth and hilling practices on total, U.S. No.1and field greening tuber yields. American J Potato Res 82: 441-50.

Bohl W H, Love S L and Salaiz T (2011) Hill shape effect on field-greening tuber yield. Presented at the Idaho Potato Conference on 19, January 2011.

Chehaibi S, Hamdi W and Abrougui K (2013) Effect of planting depth on agronomic performance of two potato verities grown in the Sahel region of Tunisia. $J$ Develop Agri Eco 5:272-276.

Etemad B and Sarajuoghi M (2012) Study of the effect of different and application timing of nitrogen fertilizer on yield and number of potato tube of agria in Ghorveh, Iran. Ann Biol Res 3:1385.

Gholipour M (1996) Desirable to determine the weight and depth of planting apple land, measuring performance and growth analysis.Msc Thesis, University of Tabriz, Iran.

Gopal J, Minocha J L and Dhaliwal H S (1998) Microtuberization in potato (Solanum tuberosum L.). Plant Cell Rep 17:794-798.

Hamid R A, Afshari H, Daliri M S, Lehi G and Toudar S R (2013) the effect of planting date, depth and density on yield and yield components of potato in shahrood (Iran). J Res Agric Sci 7: 141149.

Ilyas M and Ayub G (2017) Effect of various planting depth and mulching on yield of autumn potato crop sown at different dates. Int J Biosci 11: 166-177.

Kumar P, Singh S, Kumar R, Rawal S and Singh B P (2015) Effect of tuber planting depth onyield quality and profitability of potato (Solanum tuberosum) processing varieties. Ind $J$ Agron. 60: 139-144.

Lambion J, Toulet A, Traente M (2006) Plant protection cultivation of organic potato, Fact 2: The fight against pests. Tech. Inst. Org. Agric. Paris-France P. 4. Le CL, Thomas D, Nowbuth.

Pavek M J and Thornton R E (2009) Planting depth influences potato plant morphology and economic value. American J Potato Res 86: 56-67.

Pruski K P, Duplessis T, Lewis T, Astatkie J and Nowak P C (2001) Jasmonate effect on in vitro tuberization of Potato (Solanum tuberosum L.) cultivars under light and dark conditions. J Potato Res 44:315-325.

Naik P S and Sarkar D (1998) Effect of potassium on the in vitro potato microtuber production. Biol Plantarum 41:121-125.

\section{How to cite this article:}

Navneet Singh, Amandeep Singh and Kanwaljit Singh. 2020. Effect of Depth of Tuber Planting on Growth and Yield Parameters of Potato Crop. Int.J.Curr.Microbiol.App.Sci. 9(05): 25042507. doi: https://doi.org/10.20546/ijcmas.2020.905.286 